\title{
Electron Probe Technique for Measuring the Iron Oxidation State of Silicate Glasses
}

\author{
Ery C Hughes ${ }^{1}$, Ben Buse ${ }^{1}$ Stuart L Kearns ${ }^{1}$ and Jon D Blundy ${ }^{1}$ \\ 1. School of Earth Sciences, University of Bristol, Bristol, UK.
}

Oxygen fugacity is an important control on the chemical and physical properties of silicate melts and is therefore an important parameter to constrain in geological systems. The iron oxidation state of silicate glasses provides a useful proxy for the oxygen fugacity of natural and experimental processes [1], therefore a variety of techniques have been developed to measure $\mathrm{Fe}^{2+} / \mathrm{Fe}_{\mathrm{T}}$ (e.g., wet chemistry, Mössbauer, Raman, $\mu X A N E S$, and EELS). For geological applications, high spatial resolution is commonly required due to the small areas of glass available $(10-100 \mu \mathrm{m}$ diameter regions). Currently, $\mu$ XANES is the preferred technique due to its high precision $( \pm 0.0045)$ and spatial resolution $(<10 \times 10$ $\mu \mathrm{m})$ but, as it requires access to a synchrotron, it is not widely accessible and requires difficult sample preparation [2]. A technique using the electron probe would be far more accessible, providing an alternative to synchrotron-based techniques.

The Fe L lines are sensitive to the concentration, oxidation state and coordination of iron because they involve transitions from outer shell (3d) orbitals involved in bonding [3]. The peak position and intensity of the $\mathrm{Fe} L \alpha$ and $\mathrm{L} \beta$ change with iron concentration and oxidation state and these changes have been used to quantify the iron oxidation of silicate glasses and minerals. The Peak Shift Method uses changes in the $\mathrm{Fe} \mathrm{L} \alpha$ peak position, which correlate with $\mathrm{Fe}^{2+} / \mathrm{Fe}_{\mathrm{T}}$ for a given iron concentration [4]. The Flank Method uses changes in the ratio of the high wavelength flank of the L $\beta$ peak to the low wavelength flank of the $\mathrm{L} \alpha$ peak $\left(\mathrm{Fe} \mathrm{L} \beta_{\mathrm{f}} / \mathrm{L} \alpha_{\mathrm{f}}\right)$ [5]. This ratio correlates with the $\mathrm{Fe}^{2+}$ concentration for a given chemical system, which can be converted to $\mathrm{Fe}^{2+} / \mathrm{Fe}_{\mathrm{T}}$. The Flank Method has greater sensitivity than the Peak Shift Method [6].

Previous studies have observed that silicate glasses change redox state during electron beam irradiation, precluding high spatial resolution analysis as samples had to be moved during analysis to reduce the electron dosage per unit area [4]. Here we combine time-dependent intensity measurements, commonly used to correct of alkali migration during glass analysis [7], with the Flank Method to correct for the changes in redox state during analysis. We analysed 68 silicate glasses from a variety of studies covering a wide range of compositions $\left(43-78 \mathrm{wt} \% \mathrm{SiO}_{2}, 1.9-17.4 \mathrm{wt} \% \mathrm{FeO}_{\mathrm{T}}\right.$ and $0-12 \mathrm{wt} \% \mathrm{H}_{2} \mathrm{O}$, Figure 1a) with independently constrained iron oxidation state using wet chemistry, $\mu$ XANES and Mössbauer $\left(0.1-1.0 \mathrm{Fe}^{2+} / \mathrm{Fe}_{\mathrm{T}}\right.$, Figure $\left.1 \mathrm{~b}\right)$. Data were collected at $15 \mathrm{kV}, 10-50 \mathrm{nA}$ and a defocused beam of $4-15 \mu \mathrm{m}$ diameter. Typically, ten analyses were collected on fresh areas of glass per sample and averaged. Two TAP crystals were used to analyse $\mathrm{Fe} L \alpha_{\mathrm{f}}$ and one TAPH crystal for $\mathrm{Fe} L \beta_{\mathrm{f}}$. Fe $\mathrm{L} \beta_{\mathrm{f}} / \mathrm{L} \alpha_{\mathrm{f}}$ was calculated at every time-step by dividing $\mathrm{Fe} L \beta_{\mathrm{f}}$ by the sum of $\mathrm{Fe} L \alpha_{\mathrm{f}}$, and then extrapolated to time zero by fitting an exponential function to the data unless there was no change in the ratio over time in which case the average of the analyses was used. The corrected $F e L \beta_{f} / L \alpha_{f}$ ratio was calibrated against independently constrained $\mathrm{Fe}^{2+}$ (Figure 1c) and converted to $\mathrm{Fe}^{2+} / \mathrm{Fe}_{\mathrm{T}}$ using EPMA measured $\mathrm{Fe}_{\mathrm{T}}$ (Figure 1d).

This technique allows the iron oxidation state of low-silica glasses $\left(43-56 \mathrm{wt} \% \mathrm{SiO}_{2}, 5 \mathrm{wt} \%<\mathrm{FeO}_{\mathrm{T}}\right)$ to be analysed at high spatial resolution ( $\sim 20 \mu \mathrm{m}$ diameter region) with a precision of $\pm 0.03 \mathrm{Fe}^{2+} / \mathrm{Fe}_{\mathrm{T}}(10$ wt $\% \mathrm{FeO}_{\mathrm{T}}$ and $0.5 \mathrm{Fe}^{2+} / \mathrm{Fe}_{\mathrm{T}}$ ) and an accuracy of $\pm 0.11 \mathrm{Fe}^{2+} / \mathrm{Fe}_{\mathrm{T}}$. Both anhydrous and hydrous glasses 
were found to change oxidation state during analysis, therefore most silicate glasses require timedependent measurements for accurate quantification. Unfortunately, high-silica glasses are much more unstable than low-silica glasses, therefore high-silica glasses cannot be analysed at such high spatial resolutions [8].

References:

[1] VC Kress and ISE Carmichael, Contributions to Mineralogy and Petrology 108 (1991), p. 82.

[2] E Cottrell et al, Chemical Geology 268 (2009), p. 167.

[3] P Gopon et al, Microscopy and Microanalysis 19 (2013), p. 1698.

[4] M Fialin et al, American Mineralogist 89 (2004), p. 654.

[5] HE Höfer and GP Brey, American Mineralogist 92 (2007), p. 873.

[6] HE Höfer et al, European Journal of Mineralogy 6 (1994), p. 407.

[7] CH Nielsen and H Sigurdsson, American Mineralogist 66 (1981), p. 547.

[8] We thank RR Almeev, RE Botcharnikov, D Di Genova and JM Riker for their samples; and G Kilgour and HM Mader for their supervision.
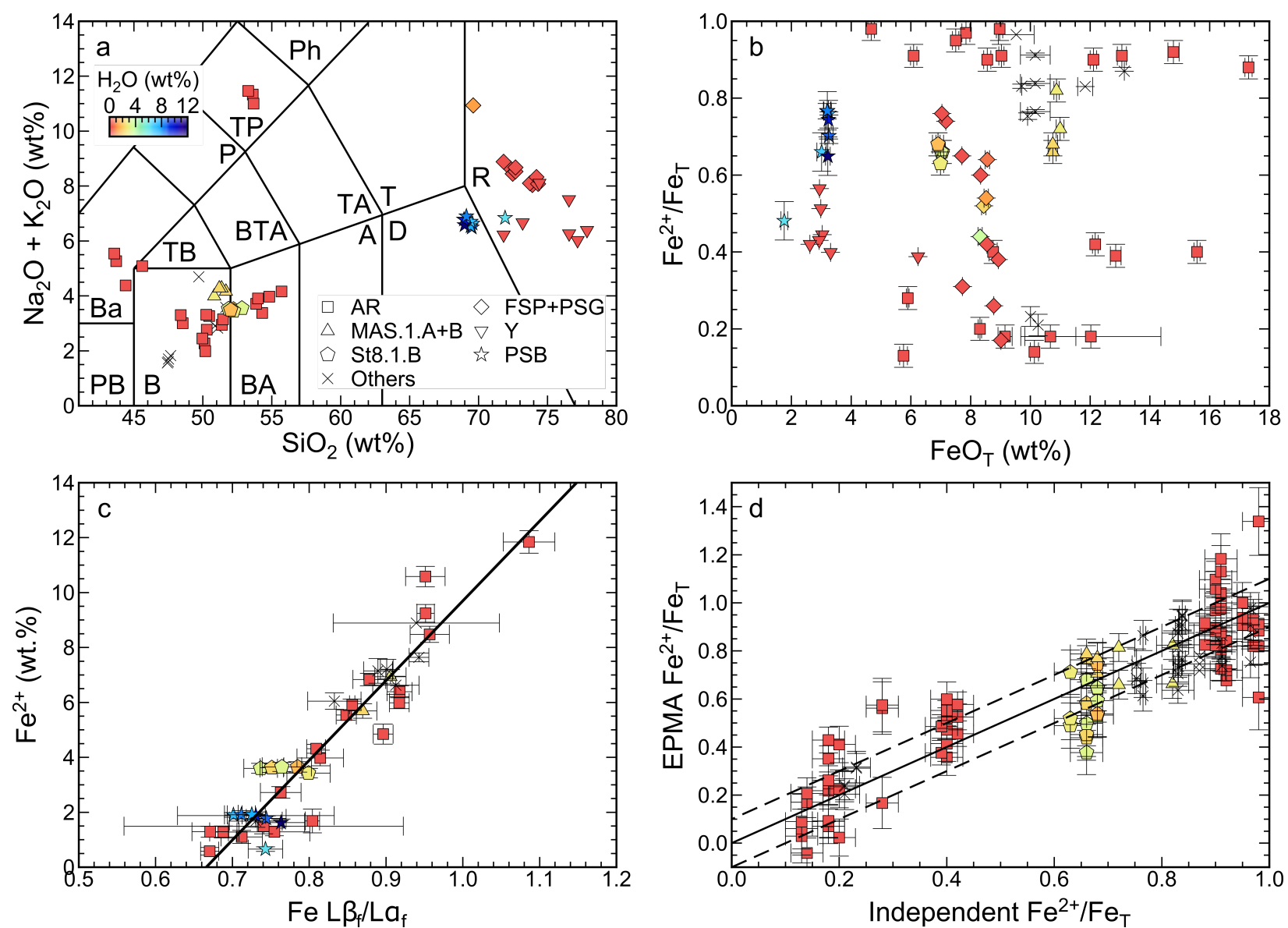

Figure 1. (a) Total alkalis $\left(\mathrm{Na}_{2} \mathrm{O}+\mathrm{K}_{2} \mathrm{O}\right)$ against silica $\left(\mathrm{SiO}_{2}, \mathrm{Na}_{2} \mathrm{O}\right.$ and $\mathrm{K}_{2} \mathrm{O}$ normalised to the volatilefree total), and (b) $\mathrm{Fe}^{2+} / \mathrm{Fe}_{\mathrm{T}}$ against $\mathrm{FeO}_{\mathrm{T}}$, for glasses analysed in this study; (c) example calibration curve of known $\mathrm{Fe}^{2+}$ against corrected $\mathrm{Fe} \mathrm{L} \beta_{\mathrm{f}} / \mathrm{L} \alpha_{\mathrm{f}}$, and (d) EPMA-derived against independently constrained $\mathrm{Fe}^{2+} / \mathrm{Fe}_{\mathrm{T}}$ for low-silica glasses. Symbol shape indicates glass composition and colour $\mathrm{H}_{2} \mathrm{O}$ content. TAS classification abbreviations: $\mathrm{PB}=$ picrobasalt, $\mathrm{B}=$ basalt, $\mathrm{BA}=$ basaltic andesite, $\mathrm{A}=$ andesite, $\mathrm{D}=$ dacite, $\mathrm{TB}=$ trachybasalt, $\mathrm{BTA}=$ basaltic trachyandesite, $\mathrm{TA}=$ trachyandesite, $\mathrm{T}=$ trachyte, $\mathrm{R}=$ rhyolite, $\mathrm{Ba}=$ basanite, $\mathrm{P}=$ phonotephrite, $\mathrm{TP}=$ tephriphonolite, and $\mathrm{Ph}=$ phonolite. 